\title{
Nurses' Knowledge, Attitude and Practice Regarding Infection Control in Operating Rooms in Port Said Hospitals
}

Samah Mohammed Mohammed Wahba, Prof. Seham Ibrahim Hamouda, Dr. Sanaa Abd El Azeem Ibrahim, Dr. Mona Abdul El Sabour Hassan

B. Sc of Nursing Suez Canal University, Professor of Nursing Administration Faculty of Nursing Tanta University, Assistant Professor of Nursing Administration Faculty of Nursing Port-Said University, Assistant Professor of Family and Community Health Nursing Faculty of Nursing Port- Said University

\begin{abstract}
Background: Nosocomial infections (NI) occur worldwide, affecting both developed and poor countries and rank as a major killer of patients of all ages. Aim:the aim of Study was to assess the nurses' knowledge, attitude and practice regarding infection control in operating rooms in Port Said HospitalsSubject and Methods: the research Design: a descriptive correlation study design was used in hospitals of three different health care sector (general, private and health insurance) in Port Said city.Sample : Tools and Procedure: Data were collected using three tools. The first tool, a questionnaire sheet, composed of two parts; first part includes personal and job characteristics, second part covers the nurses' knowledge about infection control in operating rooms. The second tool includes the nurses' attitudes scale about infection control in operating rooms. The third tool is an observation checklist to evaluate the nurses' practice regarding hospital infection. Results: The study results revealed that most of the studied nurses had satisfactory knowledge $(80 \%)$, while most of them had unacceptable attitude $(70 \%)$. As regard their practice, about half of them $(52 \%)$ had inadequate practice regarding infection control. Conclusion: it can be concluded from the present study that studied nurses had satisfactory knowledge, unacceptable attitude and about half of them had inadequate practice regarding infection control in operating rooms. Recommendations: continuous training programs, conferences and seminars about infection control are needed to improve nurses' knowledge that can be translated into good practices and positive attitudes.
\end{abstract}

Key Words: Nosocomial infection, Knowledge, Attitude, Practice, Infection control, 


\section{INTRODUCTION}

Nosocomial infections (NI), known as hospital acquired infections (HAIs) occurred to patients during receiving treatment in a hospital. Infections are considered nosocomial if they first appear within 48 hours or more after hospital admission (Parmeggiani et al., 2010). The World Health Organization (WHO) estimates that among the 190 million patients who are hospitalized each year worldwide, an average of 9 million individuals are affected by nosocomial infections and approximately one million patients die each year because of these infections (Raka et al., 2010). The statistics confirmed that the incidence of nosocomial infection in developed countries ranges between 5 to 10 per cent of all admissions to hospitals and health institutions and this percentage will increase in developing countries to about 10 to 20 per cent (Khalil, 2011).

The operating room is a high risk area for the spread of infection especially surgical site infections (Ignatavicius \& Workman, 2010). Surgical site infections (SSIs) are a major public health problem; it is the third most common health care-associated infection and contributes to $13-17 \%$ of all such infections. Most of SSIs remains a major cause of morbidity and mortality comprising of $20 \%$ of all healthcare associated infections and at least 5\% of patients undergoing surgery develop an SSI despite improvements in infection control techniques and surgical practice, and impose substantial demands on health care resources (Raiseaud, 2011; Caroline et al., 2012).

Infection control (IC) is a quality-improvement activity that focuses on improving the care of patients and protecting the health of staff (Chalmers \& Straub, 2006). In places where infection control programs were implemented, there had been a proven reduction of morbidity and mortality (Khan, 2009). Raka et al., (2010) claimed that, the aim of applying infection control practices in the operating room is to decrease surgical site infections. Effective operative techniques clearly reduce the risk of SSIs. According to Phillips (2007) sterile technique is the basis of modern surgery and therefore strict adherence to the recommended practices of sterile technique is mandatory for the safety of the patient as well as for the personnel in the operating room.

Nurses working in operating room should be trained to prevent cross infection and transmission of nosocomial infections by using aseptic technique practice, demonstrate sound knowledge and attitude in maintaining a sterile field all times to minimize spread of potential pathogens to other sites, wounds or self and help patients in having a safe operation (Taylor et al., 2008). There is advancement in infection control practices such as improved operation room ventilation, sterilization methods, barriers, surgical techniques, and availability of antimicrobial prophylaxis, but surgical site infections is still a substantial cause of morbidity and mortality among hospitalized patients (Klevens \& Edwards, 2002). Nurses should implement infection control principles and apply sterile technique principles in the operating room (Malan, 2009). 


\section{Significance of the study}

Surgical Site Infections (SSIs) incidence in Egypt is still high, these infections vary from one hospital to another according to patients' population and procedures (Bonnal et al., 2010; El-Awady et al., 2010). For example incidence in EL-Mansora University Hospital is $66 \%$. Additionally in Ain-Shams University Hospital, it ranges between $60-80 \%$ of all surgical patients. Also incidence in Cairo University Hospital detected an overall SSIs rate of $25.8 \%$ (from $4.1 \%$ in clean wound to $66.7 \%$ in contaminated wounds), and incidence in Tanta University hospital is $22.6 \%$ (66 of 292 cases) (Ahmed, 2003; Afifi et al., 2009; Khaleid et al., 2010). Although the operating room nurse has an important role in preventing and controlling the infections during operation, it was noticed that the occurrence of Surgical Site Infections is high in this area. Therefore, this study is conducted to assess nurses' knowledge, attitude and practice (KAP) regarding infection control in operating rooms in Port Said Hospitals.

\section{AIM OF THE STUDY:}

Assess nurses' knowledge, attitude and practice (KAP) regarding infection control in operating rooms in Port Said Hospitals.

\section{SUBJECT AND METHODS:}

\section{Research design:}

A descriptive correlation design was used. The study was conducted in all operating rooms in three selected hospitals representing three different health care sectors in Port Said Governorate, according to the flow rate of surgical admissions namely: PortSaid General Hospital (Governmental sector), El-Tadamon Hospital (Health insurance sector), AL-Soliman Private Hospital (Private sector). All nurses who were working in operating rooms in the pre-mentioned settings were included in the study with a total number of 50 nurses. Of these, 30 nurses working in four operating rooms in Port Said General Hospital (Surgical, Orthopedic, Gynecology and Emergency), 10 nurses working in three operating rooms in EL-Tadamon Hospital (Surgical, Gynecology and General Endoscope) and 10 nurses working in three operating rooms in AL-Soliman Hospital (Surgical, Orthopedic and Gynecology).

\section{Tools for data collection}

The study data were collected using three tools:

Tool (I): A Questionnaire Sheet composed of two parts: Part (I): includes personal and job characteristics for nurses, such as name, sex, age, level of education, social status, years of experience and training course in infection control.....etc., Part (II): adopted from Tantawy, (2000) and Ahmed, (2003), addressing questions covering the nurses' knowledge about nosocomial infections, infection control, disinfection and sterilization of surgical instrument, principle and uses of antiseptic solutions, duties of circulating nurse before surgical operation, duties of scrubbing nurse before surgical operation, cleaning and disinfection of operating room and personal protective equipment (PPE). Scoring for Knowledge Items: A correct response was scored 
"One" and the incorrect "Zero". For each area of knowledge, the scores of the items was summed up and the total divided by the number of the items, giving a mean score for the part. These scores were converted into a percent score. Knowledge was considered "satisfactory" if the percent score was $60 \%$ or higher and "unsatisfactory" if less than 60\% (El-Ghareb, 2011; Ezz-Eldeen, 2011).

Tool (II): Nurses' attitude scale that includes their attitude related to infection control in operating room, as nurses' behavior when the sterile gloves rupture during work, nurses' behavior if they have wound in the hand during work, nurses' behavior if blood spills on the ground in operating room, nurses' behavior when dealing with non sterile instruments during work (Abd Elaziz, 2009). Scoring for Nurses' Attitude: The scale was measured on five points Likerat Scales ranging from strongly agree, agree, neutral, disagree, and strongly disagree respectively. 1 for responses: strongly agree, agree, neutral, disagree, and strongly disagree. Score of items were summed up with total score divided by number of items giving mean score for the attitude. Total score was converted into a percent score, and means and standard deviations were computed. The attitude was considered "Positive" if percent score $60 \%$ or more and "Negative" if less than 60 (Wall, 2009).

Tool (III): Observational Checklist adopted from Taylor et al., (2008) and Perry, (2010) to evaluate the nurses' performance in relation to hospital infection. It includes 7 procedures to investigate important infection control measures used in operating room namely hand washing technique, gloving technique, gowning technique, preparing sterile work area, role of scrub nurse, role of circulating nurse, cleaning equipments in preparing for sterilization. Scoring for Observed Performance: The items observed to be done were scored "One" and the items not done were scored" Zero". For each area, the scores of the items were summed up and the total divided by the number of the items, giving a mean score for the part. These scores were converted into a percent score. The practice was considered "adequate" if the percent score was $60 \%$ or more and "inadequate" if less than 60\% (Ezz Eldeen, 2011).

\section{Operational design:}

This includes content validity, reliability of the tool, pilot study and field of work. Regarding content validity, it entails that tools of data collection were tested for content validity by a panel of six experts in the Faculty of Nursing in Port Said. Necessary modifications were done according to the experts' opinions. Reliability of the tools was done by using (test and retest) measurement and necessary consumed time to be sure of the consistency of answers. Reliability of the tool was assured by means of Cronbach's alpha; it indicated that the tool has a reliability of 0.85 for knowledge, 0.82 for attitude and 0.88 for practice. A pilot study was carried out after the development of the study tools, and before the data collection phase. It was carried out on $10 \%$ of the nurses who fulfilled criteria of the study then these nurses were excluded from the original sample, necessary modification were done for the tool after pilot study. The actual study was carried out in the period from June to December, 2013. The researcher met the respondents during the three shifts to distribute the 
questionnaire. During these meetings, the researcher explained the purpose of the study and how to complete the questionnaire and assured the respondents anonymity of answers, and that information will be used for scientific research only and will be confidential. The respondents filled the questionnaire sheet individually by themselves. Completion of nurses' questionnaire sheet took 20-35 minutes. The process of observation was then done during the regular work of the nurse using the observation checklist. In order to cover all seven checklists, nurses were observed for three times covering the three shifts according to their schedule.

\section{Ethical Considerations:}

A brief explanation of the aim of the study was given to the hospital director, head nurse, and each nurse included in the study. Stressing on confidentiality of the collected information, to be familiar with the importance of their participation and to take their agreement for inclusion in the study. The researcher emphasized that participation were absolutely voluntary and each nurse has the right to withdraw from the study any time thereafter with no questioning and confidentiality was assured.

\section{RESULTS:}

Table (1): includes personal data and job characteristics of the studied nurses. Results showed that the majority of the nurses $(96 \%)$ were females, nearly three quarters (72\%) of them had diploma from nursing school, compared to $8 \%$ who had bachelor degree of nursing, about two third of them $(68 \%)$ were married, nearly half of them (48.0\%) attended courses about infection control, the majority of them (90\%) mentioned that there is an infection control committee where they work. Moreover half of them $(51.1 \%)$ reported that the infection control committee is active.

Table (2): displays knowledge, attitude and practice of the studied nurses regarding infection control in operating rooms in the studied hospitals. Data revealed that, most of the studied nurses $(80 \%)$ had satisfactory knowledge, while most of them $(70 \%)$ had unacceptable attitude, as regard their practices more than half of them (52\%) had inadequate practices regarding infection control. The highest percentage of knowledge regarding infection control in operating room was detected in Al-Tadamon health insurance hospital, where $90 \%$ of the studied nurses had satisfactory knowledge.

Table (3): illustrates relation between nurses' knowledge, attitude and practice regarding infection control and their personal and job characteristics in the studied hospitals. Results showed that there was no statistically significant association between total percentage of nurses' knowledge regarding infection control and their personal job characteristics, except in relation to sex and if committee of infection control is active were a statistically significant association were detected. Results also showed that there was no statistically significant association between personal and job characteristics and total percentage of nurses' attitude regarding infection control, except in relation to nursing qualification. In the meantime no statistically significant association was found between personal job characteristics and total percentage of nurses' practice regarding infection control. 
Table (4): delineates the correlation between knowledge, attitude and practice regarding infection control in operating rooms of the total sample of nurses in the studied hospitals. Results revealed that, nurses' knowledge regarding infection control was negatively correlated with their attitude regarding infection control in operating rooms. Also data indicated that attitude of the studied nurses negatively correlated with their practice.

Table (1): Personal and job characteristics of the studied nurses $(n=50)$

\begin{tabular}{|c|c|c|}
\hline \multirow[t]{2}{*}{ Personal data and Job characteristics } & \multicolumn{2}{|c|}{ Total $(n=50)$} \\
\hline & No. & $\%$ \\
\hline $\begin{array}{l}\text { Sex } \\
\quad \text { Male } \\
\text { Female } \\
\end{array}$ & $\begin{array}{c}2 \\
48 \\
\end{array}$ & $\begin{array}{r}4.0 \\
96.0 \\
\end{array}$ \\
\hline $\begin{array}{l}\text { Age } \\
\text { Mean } \pm \text { SD }\end{array}$ & \multicolumn{2}{|c|}{$34.02 \pm 10.80$} \\
\hline $\begin{array}{l}\text { Nursing Qualifications } \\
\text { Diploma of nursing school } \\
\text { Bachelor of nursing }\end{array}$ & $\begin{array}{c}36 \\
4\end{array}$ & $\begin{array}{c}72.0 \\
8.0\end{array}$ \\
\hline $\begin{array}{l}\text { Marital status } \\
\text { Married } \\
\text { Single } \\
\text { Widow }\end{array}$ & $\begin{array}{l}34 \\
14 \\
2\end{array}$ & $\begin{array}{c}68.0 \\
28.0 \\
4.0\end{array}$ \\
\hline $\begin{array}{l}\text { Experience } \\
\text { Mean } \pm \text { SD }\end{array}$ & \multicolumn{2}{|c|}{$15.28 \pm 10.36$} \\
\hline $\begin{array}{l}\text { Attended courses about infection control } \\
\text { Yes } \\
\text { No }\end{array}$ & $\begin{array}{l}24 \\
26\end{array}$ & $\begin{array}{l}48.0 \\
52.0\end{array}$ \\
\hline $\begin{array}{l}\text { Presence of infection control committee } \\
\text { Yes } \\
\text { No } \\
\text { Don't known }\end{array}$ & $\begin{array}{c}45 \\
1 \\
4\end{array}$ & $\begin{array}{l}90.0 \\
2.0 \\
8.0\end{array}$ \\
\hline $\begin{array}{l}\text { Is the committee active } \\
\text { Yes } \\
\text { No }\end{array}$ & $\begin{array}{l}23 \\
22\end{array}$ & $\begin{array}{l}51.1 \\
48.9\end{array}$ \\
\hline
\end{tabular}


Table (2): Knowledge, attitude and practice of the studied nurses regarding infection control in operating rooms $(n=50)$

\begin{tabular}{|c|c|c|c|c|c|c|c|c|c|}
\hline \multirow[t]{2}{*}{ Item } & \multicolumn{2}{|c|}{$\begin{array}{l}\text { Al-Soliman } \\
\text { Hospital } \\
(\mathbf{n}=10)\end{array}$} & \multicolumn{2}{|c|}{$\begin{array}{c}\text { Port Said } \\
\text { General } \\
\text { Hospital } \\
(\mathbf{n}=\mathbf{3 0})\end{array}$} & \multicolumn{2}{|c|}{$\begin{array}{c}\text { Al-Tadamon } \\
\text { Hospital } \\
(\mathbf{n}=\mathbf{1 0})\end{array}$} & \multirow[t]{2}{*}{$\begin{array}{c}\text { Test of sig. } \\
\text { МCp }\end{array}$} & \multicolumn{2}{|c|}{$\begin{array}{c}\text { Total } \\
(\mathbf{n}=\mathbf{5 0})\end{array}$} \\
\hline & No. & $\%$ & No. & $\%$ & No. & $\%$ & & No. & $\%$ \\
\hline Knowledge & \multirow{3}{*}{$\begin{array}{l}3 \\
7\end{array}$} & \multirow{3}{*}{$\begin{array}{l}30.0 \\
70.0\end{array}$} & \multirow{3}{*}{$\begin{array}{c}6 \\
24\end{array}$} & \multirow{3}{*}{$\begin{array}{l}20.0 \\
80.0\end{array}$} & \multirow{3}{*}{$\begin{array}{l}1 \\
9\end{array}$} & \multirow{3}{*}{$\begin{array}{l}10.0 \\
90.0\end{array}$} & \multirow{3}{*}{$\mathrm{p}=0.548$} & \multirow{3}{*}{$\begin{array}{l}10 \\
40\end{array}$} & \multirow{3}{*}{$\begin{array}{l}20.0 \\
80.0\end{array}$} \\
\hline Unsatisfactory $(\leq 60 \%)$ & & & & & & & & & \\
\hline Satisfactory $(>60 \%)$ & & & & & & & & & \\
\hline Mean \pm SD & \multicolumn{2}{|c|}{$64.24 \pm 7.22$} & \multicolumn{2}{|c|}{$66.44 \pm 8.83$} & \multicolumn{2}{|c|}{$70.16 \pm 6.31$} & $p=0.260$ & \multicolumn{2}{|c|}{$66.75 \pm 8.17$} \\
\hline \multicolumn{10}{|l|}{ Attitude } \\
\hline Unacceptable $(\leq 60 \%)$ & 7 & 70.0 & 18 & 60.0 & 10 & 100.0 & \multirow{2}{*}{$\mathrm{p}=0.046^{*}$} & 35 & 70.0 \\
\hline Acceptable $(>60 \%)$ & 3 & 30.0 & 12 & 40.0 & 0 & 0.0 & & 15 & 30.0 \\
\hline Mean \pm SD & \multicolumn{2}{|c|}{$57.14 \pm 11.66$} & \multicolumn{2}{|c|}{$59.52 \pm 19.23$} & \multicolumn{2}{|c|}{$54.29 \pm 6.02$} & $\mathrm{p}=0.611$ & \multicolumn{2}{|c|}{$58.0 \pm 14.55$} \\
\hline Practice & \multicolumn{2}{|c|}{$(\mathrm{n}=10)$} & \multicolumn{2}{|c|}{$(n=30)$} & \multicolumn{2}{|c|}{$(\mathrm{n}=10)$} & \multirow{3}{*}{$\mathrm{p}=0.001^{*}$} & \multirow{3}{*}{$\begin{array}{l}26 \\
24\end{array}$} & \multirow{3}{*}{$\begin{array}{l}52.0 \\
48.0\end{array}$} \\
\hline In adequate $(\leq 60 \%)$ & 2 & 20.0 & 14 & 46.7 & 10 & 100.0 & & & \\
\hline Adequate $(>60 \%)$ & 8 & 80.0 & 16 & 53.3 & 0 & 0.0 & & & \\
\hline Mean \pm SD & \multicolumn{2}{|c|}{$81.1 \pm 9.58$} & \multicolumn{2}{|c|}{$74.6 \pm 18.94$} & \multicolumn{2}{|c|}{$63.5 \pm 7.51$} & $\mathrm{p}=0.048^{*}$ & \multicolumn{2}{|c|}{$73.71 \pm 16.51$} \\
\hline
\end{tabular}

MCP: $p$ value for Monte Carlo test $p: p$ value for $F$ test (ANOVA) for comparing between the different studied groups

$*$ : Statistically significant at $\mathbf{p} \leq \mathbf{0 . 5}$ 
Table (3): Relation between job characteristics of the studied nurses and their knowledge, attitude and practice regarding infection control in operating room at the study hospitals.

\begin{tabular}{|c|c|c|c|}
\hline $\begin{array}{l}\begin{array}{l}\text { Personal data and job } \\
\text { characteristics }\end{array}\end{array}$ & Total knowledge & Total attitude & Total practice \\
\hline $\begin{array}{l}\text { Sex } \\
\quad \text { Male } \\
\text { Female } \\
\end{array}$ & $\begin{array}{l}55.56 \pm 16.70 \\
67.21 \pm 7.63 \\
\end{array}$ & $\begin{array}{l}64.29 \pm 10.10 \\
57.74 \pm 14.72 \\
\end{array}$ & $\begin{array}{l}73.19 \pm 14.06 \\
73.73 \pm 16.74 \\
\end{array}$ \\
\hline tp & $0.047^{*}$ & 0.538 & 0.964 \\
\hline $\begin{array}{l}\text { Age } \\
\qquad \begin{array}{l}20>26 \\
26>30 \\
30>35 \\
>35\end{array}\end{array}$ & $\begin{array}{l}67.92 \pm 9.19 \\
69.01 \pm 2.91 \\
67.94 \pm 5.07 \\
65.07 \pm 9.23 \\
\end{array}$ & $\begin{array}{c}55.24 \pm 7.38 \\
63.49 \pm 10.38 \\
50.0 \pm 10.10 \\
58.50 \pm 19.64 \\
\end{array}$ & $\begin{array}{c}73.90 \pm 19.54 \\
78.65 \pm 13.45 \\
85.84 \pm 3.83 \\
71.06 \pm 15.52 \\
\end{array}$ \\
\hline${ }^{F} \mathbf{p}$ & 0.608 & 0.507 & 0.495 \\
\hline $\begin{array}{l}\text { Nursing qualifications } \\
\text { Diploma of nursing school } \\
\text { Diploma of technical Institute } \\
\text { Bachelor of nursing }\end{array}$ & $\begin{array}{l}65.69 \pm 8.24 \\
68.80 \pm 8.37 \\
67.13 \pm 8.19\end{array}$ & $\begin{array}{l}59.24 \pm 10.03 \\
48.57 \pm 22.54 \\
71.43 \pm 11.66\end{array}$ & $\begin{array}{l}75.74 \pm 16.42 \\
71.14 \pm 13.10 \\
68.83 \pm 26.54\end{array}$ \\
\hline${ }^{\mathbf{F}} \mathbf{p}$ & 0.574 & $0.016{ }^{*}$ & 0.598 \\
\hline $\begin{array}{l}\text { Marital status } \\
\quad \text { Married } \\
\text { Single } \\
\text { Widow } \\
\end{array}$ & $\begin{array}{l}65.74 \pm 7.26 \\
69.11 \pm 10.40 \\
65.05 \pm 7.20 \\
\mathrm{~F} p=0.430\end{array}$ & $\begin{array}{c}57.14 \pm 15.15 \\
56.12 \pm 11.84 \\
78.57 \pm 10.10 \\
F_{p}=0.114\end{array}$ & $\begin{array}{c}75.87 \pm 15.89 \\
70.57 \pm 18.92 \\
60.84 \pm 2.56 \\
\mathrm{~F}_{\mathrm{p}}=0.334\end{array}$ \\
\hline $\begin{array}{l}\text { Experience } \\
\quad 0>5 \\
5>10 \\
10>15 \\
>15\end{array}$ & $\begin{array}{l}65.01 \pm 10.49 \\
69.58 \pm 5.88 \\
67.07 \pm 4.44 \\
65.06 \pm 9.34\end{array}$ & $\begin{array}{c}61.22 \pm 13.59 \\
56.19 \pm 8.48 \\
60.71 \pm 7.14 \\
58.44 \pm 19.17\end{array}$ & $\begin{array}{c}67.21 \pm 20.68 \\
76.87 \pm 14.80 \\
80.12 \pm 22.79 \\
71.0 \pm 15.25\end{array}$ \\
\hline${ }^{\mathbf{F}} \mathbf{p}$ & 0.408 & 0.881 & 0.444 \\
\hline $\begin{array}{l}\text { Attended courses about infection } \\
\text { control } \\
\text { No } \\
\text { Yes } \\
\end{array}$ & $\begin{array}{l}65.74 \pm 10.01 \\
67.65 \pm 5.94\end{array}$ & $\begin{array}{l}57.14 \pm 14.29 \\
58.33 \pm 15.14\end{array}$ & $\begin{array}{l}75.86 \pm 18.70 \\
71.54 \pm 14.35\end{array}$ \\
\hline${ }^{t} \mathbf{p}$ & 0.423 & 0.778 & 0.371 \\
\hline $\begin{array}{l}\text { Presence of infection control } \\
\text { committee } \\
\text { No } \\
\text { Yes } \\
\text { Don't known } \\
\end{array}$ & $\begin{array}{l}64.35 \pm- \\
66.38 \pm 8.36 \\
71.41 \pm 5.83\end{array}$ & $\begin{array}{c}57.14 \pm- \\
58.41 \pm 15.17 \\
53.57 \pm 7.14 \\
\end{array}$ & $\begin{array}{c}88.55 \pm- \\
74.94 \pm 15.13 \\
56.17 \pm 24.28\end{array}$ \\
\hline${ }^{t} \mathbf{p}$ & $\mathrm{F}_{\mathrm{p}}=90.487$ & ${ }^{F} p=0.821$ & $\mathrm{~F}_{\mathrm{p}}=0.059$ \\
\hline $\begin{array}{l}\text { Is the committee active } \\
\text { No } \\
\text { Yes }\end{array}$ & $\begin{array}{l}63.59 \pm 9.29 \\
68.98 \pm 6.84\end{array}$ & $\begin{array}{l}58.50 \pm 15.59 \\
58.39 \pm 15.48\end{array}$ & $\begin{array}{l}75.85 \pm 13.44 \\
73.18 \pm 16.40\end{array}$ \\
\hline${ }^{\mathbf{t}} \mathbf{p}$ & $\mathbf{0 . 0 3 3}^{*}$ & 0.980 & 0.561 \\
\hline
\end{tabular}

F: F test (ANOVA) t: Student t-test $\quad *$ : Statistically significant at $p \leq 0.05$ 
Table (4): Correlation between knowledge, attitude and practice of total sample $(n=$ 50)

\begin{tabular}{|l|c|c|c|c|}
\hline \multicolumn{2}{|c|}{} & Knowledge & Attitude & Practice \\
\hline \multirow{2}{*}{ Knowledge } & $\mathbf{R}$ & - & $-0.386^{*}$ & 0.046 \\
\cline { 2 - 4 } & $\mathbf{P}$ & - & 0.006 & 0.749 \\
\hline \multirow{2}{*}{ Attitude } & $\mathbf{R}$ & $-0.386^{*}$ & - & -0.122 \\
& $\mathbf{P}$ & 0.006 & - & 0.398 \\
\hline \multirow{2}{*}{ Practice } & $\mathbf{R}$ & 0.046 & 0.077 & - \\
\cline { 2 - 6 } & $\mathbf{P}$ & 0.749 & 0.833 & - \\
\hline
\end{tabular}

r: Pearson coefficient *: Statistically significant at $\mathbf{p} \leq 0.05$

\section{DISCUSSION:}

Nosocomial infections are an important cause of increased morbidity, prolonged hospitalization and higher health care costs. These infections occur within a health care facility and may affect both the patient and the health care worker. These infections are much more serious than those acquired in the community Adinma et al., (2009).

The results of the present study showed that the majority of the total studied nurses had satisfactory knowledge regarding infection control, more than two thirds of them had unacceptable attitude, while more than half of them had inadequate practices and a statistical differences in attitude and practice toward infection control were detected between the three studied hospitals. These results are in agreement with El-Ghareb, (2011) who reported that most of the studied nurses had a satisfactory level of knowledge and had unsatisfactory level of practice related to infection control measures. Similarly they are in accordance, with Taneja et al., (2009) who found that the mean reported knowledge of staff nurses regarding infection control measures was high. They are also in the same line with Labeau et al. (2008); Vandijck et al. (2008); Ezz-Eldeen (2011) who reported that poor attitude could be due to failure to adopt favorable behavior, attitude during nursing training at school.

Results of the present study are also in agreement with Ezz-Eldeen, (2011) in her study about assessment of knowledge and practice of emergency nurses regarding infection control in public and private hospitals in Port Said, who found that none of these nurses had adequate performance regarding infection control. In the same line, Taneja et al., (2009) in his study about evaluation of knowledge and practice amongst nursing staff toward infection control measures in a tertiary care hospital in India, found that the mean reported practice of staff nurses regarding infection control measures was low. Similarly, El-Ezaby, (2004) in his study about effect of a training program developed for nurses about universal precautions for infection control in health care centers in Port Said, has also reported that most nurses' performance was 
unsatisfactory about infection control. These results are also supported by Younis, (2000) in his study about assessment of health personnel knowledge, attitude and practice in relation to infection control in general surgical units.

Nurses' practice in Al-Soliman private hospital, recorded better score than the other two hospitals, but unfortunately most of nurses in this hospital had unacceptable attitude regarding infection control. This might be due to sufficient supplies and resources and adequate follow up, sufficient numbers of staff nurses and presence of monitoring system as a camera for supervision of the staff nurses, also policy of punishment for neglecting patient care, and attending training workshop before work in hospital. Similarly, Siegel et al. (2007); Quiros e al., (2007); Rezae \& Rahimi, (2009) reported that good knowledge is necessary for good practice for infection control, but it is not sufficient for good attitude. Continuing training, making attitude, supervision and evaluation of nurses' practices are recommended for infection control, and a first step is to implement interventions that influence health care workers' attitudes towards the recommended practice. Moreover, Vought-O'sullivan et al., (2007) stressed on the importance of competency-based continuing education and presence of evaluation system for nurses during their work regarding their knowledge and practical skills.

The studied nurses in Al-Tadamon health insurance hospital, had the higher score of knowledge than the other two hospitals, unfortunately all of the nurses had inadequate practice and unacceptable attitude of infection control, this might be due to carelessness and absence of motivation, less supervision and absence of role model. Added to these, are the workload due to shortage of nursing staff, low experience , shortage of training courses about infection control and less adherence to hospital policies. The results are in agreement with Ahmed (2003); Seltzer et al. (2009) who stated that shortage of staff nurses and increasing nurse's responsibilities lead to deficient practice and attitude. Also, Qalawa (2009) reported that shortage of staff has its negative effect on both practice and attitude.

Results showed that there was no statistically significant association between total percentage of the nurses' knowledge regarding infection control and job characteristics (as nursing qualifications, age, experience), except in relation to sex and if infection control committee is active. The result is in agreement with Monntazeria, (2005); Amerion \& Butsashvili et al., (2010); Ezz-Eldeen, (2011) Who reported that there was no significant relationship between the mean scores of nurses' knowledge regarding infection control and their clinical experience. On the other hand, Khorasani, (2003) claimed that the years of employee's experiences do influence their knowledge. These findings are in accordance with Parmeggiani, (2010) who reported that lower knowledge is linked to the underuse of appropriate infection control measures.

Results showed that there was no statistically significant association between nurses' attitude regarding infection control and job characteristics, and also, data revealed that there was no statistically significant association between nurses' practice 
regarding infection control and job characteristics, except in relation to nursing qualification. The result is in the same line with, Burns et al., (2001) who reported that the higher the level of nursing education, the more positive the nurses' attitudes become, and certificate nurses had higher mean positive attitude than degree nurses. The finding in contradict with McCann et al. (2006) who reported that older and more qualified nurses had more supportive attitudes than younger and less experienced nurses. Meanwhile, Pittet (2000); Jumaa (2005) found that educational background is one of the factors influencing compliance with good practices; indeed, education works synergistically with other factors, attitude and practice.

Results revealed that, nurses' knowledge regarding infection control was negatively correlated with their attitude. Also data indicated that nurses' attitude regarding infection control was negatively correlated with their practice of the studied nurses regarding infection control in operating rooms. This result is in agreement with, Hadley \& Roques (2007); Najeeb \& Taneepanichsakul (2008) who revealed that negative correlation was found between knowledge and attitude regarding infection control. The result is supported by Collins (2008) who found that, practice and attitude are influenced by knowledge. On the same line, Grota et al. (2009); EzzEldeen (2011) reported that barriers such as attitude, lack of motivation, supervision and lack of some knowledge interfere with healthy infection prevention practice. The result is in contrast with Behiry (2010) who found that a significant improvement of infection control practice with knowledge improvement.

\section{CONCLUSION:}

\section{Based on the findings of the present study, it can be concluded that:}

Studied nurses had unacceptable practice and attitude regarding infection control in operating rooms in Port Said Hospitals. A negative correlation is found between nurses' knowledge and nurses' attitude regarding infection control in operating rooms in the studied hospitals as well as a negative correlation between nurses' practice and nurses' attitude.

\section{RECOMMENDATIONS:}

Based on the study findings it is recommended: to develop a system for periodical nurses' evaluation to determine strategies for upgrading their knowledge and enhancing their practices. Continuous and strict follow up for nurses during work and continuous evaluation of their practice and correction of poor practices are needed. Also developing strict system for reward and punishment would be of great value. 


\section{REFERENCES:}

Abd Elaziz K.M. and Baker I.M. (2009): Assessment of knowledge, attitude and practice of hand washing among health care workers in Ain Shams University Hospitals in Cairo. Journal of Prevention Medical Hygiene; 50(1): 19-25.

Ahmed, F.M. (2003): Assessment of nurses' knowledge and practice about postoperative wound infection. UN published Master Thesis. Suez Canal University, Egypt, P.p. 54-59.

Adinma, E.D., Ezema, C. and Asuzu, M.C. (2009): Knowledge and practice of universal precautions against blood borne pathogens amongst house officers and nurses in tertiary health institutions in Southeast Nigeria. Niger J Clin Pract; 12(4): 398-402.

Afifi, I.K., Labah, E.A. and Khalil M.A. (2009): Surgical Site Infections after Elective General Surgery in Tanta University Hospital: Rate, Risk factors and Microbiological profile, Faculty of Medicine, Tanta University, Egyptian Journal of Medical Microbiology, (2): P.p. 61-64.

Behiry I.K.(2010): Strategy For Improving Compliance To The Infection Control Program. The $19^{\text {th }}$ Annual Conference of the Egyptian Society for Infection Control\& The $1^{\text {ST }}$ Annual Conference of the Egyptian Safety Association " On The Way to SafeLand" $29^{\text {th }}$ October- $1^{\text {st }}$ November, Alexandria.

Bonnal C., Mourvillier B., Bronchard R., PaulaD.D. Lefever L.A., Lucet J.C.(2010): Prospective Assessment of Hospital-acquired blood stream infections: How many may be preventable. Qual safe health care; 19(5); P.p.1-5.

Burns, N. and Grove, S.K. (2001): Understanding Nursing Research. ( $2^{\text {nd }}$ Ed). United States of America: W.B. Saunders Company: P.p. 231-20.Caroline, B.R., and Mary T.K. (2012): Textbook of Basic Nursing, Eighth Edition, Lippincott, Philadelphia comp, P.p. 536-611.

Collins, R.(2008): Adverse impact of surgical site infections in English hospitals. Journal of Hospital Infection 2008;60:93-103.

EL-Awady, M.Y., Harak, M.K., Abdelrahman, A.A., ELmorsy, E.A., Ragab, A.R., Makhdoom, N.K. and Allam A.R. (2010): Hospital Acquired Infection in MadinahKAS, Epidemiology and intervention for reduction. Journal of medicine and biomedical sciences; ISN: 2078-0273: P.p. 41-46. 
El-Ezaby, H.H. (2004): Effect of a training program developed for nurses about universal precaution for infection control in health care centers in Port-Said Doctorte, Thesis Community Health Nursing. Faculty of Nursing, Suez Cana University. P. 92.

El-Ghareb, E. (2011): Assessment Of Nurses Performance Regarding Infection Control Measures In Caring For Patient with Post Operative Wound in Port-Said, Thesis Medical Surgical Nursing. Faculty of Nursing, Port Said University. P.p.124142.

Ezz-Eldeen, A.I. (2011): Assessment of knowledge and practice of emergency nurses regarding infection control in public and privet hospitals in Port-Said, Thesis Medical Surgical Nursing. Faculty of Nursing, Suez Cana University. P. 129.

Hadley, M.B. and Roques, A. (2007): Nursing in Bangladesh: Rhetoric and reality. Social Science and Medicine. 21, P.p. 1153-1165.

.Grota P.G., Meinzen S., Rine P.B.(2009): HIPP Lead to Self-health,healthy Infection Prevention Practices in Intensive Care Units. Critical Care Nursing Quarterly; 32(3):242-250.

Ignatavicius, D.D. and Workman, M.L. (2010): Medical surgical nursing patientcentered Collaborative Care, (6 ${ }^{\text {th }}$ ed). Saunders Elsevier (25): 442.

Klevens, R.M. and Edwards J.R. (2002): Estimating Health Care Associated Infections and Deaths in USA Hospitals. Infection Control Hospital. Epidemiology. "Journal of Public Health Reports, 85 (12 ${ }^{\text {th }}$ ed): P.p. 160-166.

Khaleid, M.A., Abdel-Khalek, Z.I. and El-Tahlawy, E.M. (2010): Surgical Site Infections and Associated Risk Factors in Egyptian Orthopedic Patients, Cairo University, National Research Center, Egypt. Journal of American Science 2010;6 (7): 272-280. http://www.americanscience.org.

Labeau, S.O., Vandijck, D.M., Vandewoude, K.H. and Bot S.I. (2008): Obstacles to implementing evidence- based guidelines. Respire Care; (53): 505-506.

Malan, K. (2009): Registered Nurses' Knowledge of Infection Control and Sterile Technique Principles in the Operation Room Complex of Private Hospitals: Published Master thesis Master, Faculty of Health Science at Nelson Mandela Metropolitan University. P.p.77-96.

McCann, T., Clark, E., McConachie, S. (2006): Accident and emergency nurses' attitudes towards patients who self-harm. Accident and Emergency Nursing, 14, 4-10 doi:10.1016/j.aaen.2006.10.005

Najeeb, N. and Taneepanichsakul, S. (2008): Knowledge, Attitude and Practice of standard and transmission- based precaution in tertiary and secondary heath care 
setting f Maldives. Master Dissertation, College of Public Health Sciences, Chulalongkorn University. Journal of Health Research, (22 ${ }^{\text {nd }}$ ed), P.p. 45-48.

Parmeggiani, C., Abbate, R., Marinelli, P. and Angelillo, I.F. (2010): Healthcare workers and hath care-associated infection: knowledge, attitude, and behavior in emergency departments in Italy.BMC Infect Dis; (10): 35.

Qalawa, SH.A. (2009): Developing of an instructional Scheme for mastectomized patients on the prevention of arm lymph edema. Doctorate Degree, Faculty of Nursing. Suez Canal University, Egypt.

Quiros, D., Lin, S. and Larson, E.L. (2007): Attitude toward practice guidelines among intensive care unit personnel: across-sectional anonymous survey. Heart Lung; (36): 87-97.

Rezae, B. and Rahimi, M.(2009): Knowledge and Practice of Nursing Staff about Nasocomial Infections Control, Isfahan, Ira, Journal of Health System; 1(2): 10.

Seltzer, J., McGrow, K., Horsman, A., \& Korniewicz, D. M. (2009): Awareness of surgical site infection for advanced practice nurses. American Association of Continuing Nursing Clinical Issues, (13): 398-409.

Tantawy, N.M. (2000): Nurses Knowledge and Practice related to Infection Control in Operating Room. Unpublished Master Thesis, Faculty of Nursing, Zagazig University. P.p. 100.

Taylor, C.R., Lemon, P., Lillis, C. and Lynn P. (2008): Fundamentals of Nursing: The Art and Science of Nursing Care. $6^{\text {th }}$ ed., Wolters Kluwer/ Lippincott Co., Williams\& Wilkins, Philadelphia, P.p.701-707, 712.

Taneja, J., Bibha Bati, M., Aradhana, B., Poonam, L. and Vinita D. (2009): Evaluation of knowledge and practice amongst nursing staff toward infection control measures in a tertiary care hospital in India. Can J Infect Control, (24): 104-107.

Vandijck, D.M., Labeau, S.O. and Blot, S.I. (2008): Facilitating clinician adherence to guidelines in the intensive care unit. Crit Care Med; 36(5): 655-665.

Vought O., Sullivan, V., Meehan, N.K., Havice, P.A. and Pruit, R.H. (2007): Continuing education: A National imperative for school nursing practice .J. Sch . Nurse; Bailliere Tindall, London, 22(1 ${ }^{\text {st }}$ ed): P. 26.

Wilson, J. (2006): Infection Control in Clinical Practice, $\left(3^{\text {rd }}\right.$ ed). Elsevier, CHNA, P.261. 
Youniss, A. (2000): Assessment of health personnel knowledge, attitude and practice in relation to infection control in a general surgical units. Unpublished Master Thesis, High Institute of Nursing. Ain Shams University, Cairo, P.p. 98-105. 


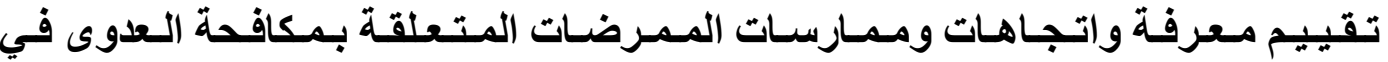

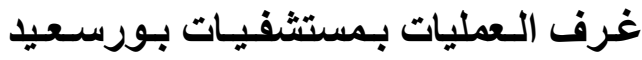

سماح محمد محمد و هبة ، ا. د/ سهام إبر اهيم حمودة، ا.م. د / سناء عبد العظيم إبر اهيم، ا.م. د / منى عبد الصبور

$$
\text { حسن }
$$

بكالوريوس تمريض جامعة فناة السويس ـ أستاذ إدارة التمريض كلية التمريض جـامعة طنطا ـ أستاذ مساعد إدارة التمريض كلية التمريض جـامعة بورسعيد ـ أستاذ مساعد تمريض صحة الأسرة و المجتمع كلية التمريض جامعة

\section{الخلاصة}

العدوى هي إحدى أهم المشاكلِ في المؤسسات الصحيةِ حول العالم. هدف الدر اسةِِ هو تُقيّمَ معرفةً و اتجاهات و ممارسات فريق التمريض المتعلقة بمكافحه العدوى في غُرَفِ العمليات في مستشفيات بورسعيد وتمت هذه الدراسةِ في ثلاثة قطاعاتِ رعاية صحيةِ مختلفةِ (عامّ وخاصّ و تأمين صحي). و اشتَتَلتُ الدر اسةِ على 50 ممرضة وممرض هي كل القوى البشرية التي كَانتْ تَعْملُ في غُرَفِ العمليات في المستشفيات المختارةِ. تم جمع البيانات باستخدام ثلاث أدوات مختلفة، الأداة الأول هي استمارة استبيان وتَحتوي علي جزئين، الجزء الأول يتكون من البنود ذات الصلة بالخصائص الثخصية لفريق التمريض و الجزء الثاني يغطى معلومات عن فريق التمريض حول السيطرة على العدوى. والاستمارة الثانية تغطى اتجاه فريق التمريض حول السيطرة على العدوى في غرف العمليات. الأداةِ الثالثة عبارة عن استمارة ملاحظه لتَفيبم أداءِ فريق التمريض فيما يتعلق بمكافحه العدوى في غرف العمليات. وقد أظهرت نَتائجُ الدر اسةَ بأن أغلب فريق التمريض لديهم معرفةُ كافية عن مكافحه العدوى في غرف العمليات، بينما كَانَ معظمهم لديهم اتجاهات سلبية عن بن مكافحه العدوى ، وكان أكثر من نِصْفهرِ بقليل يستخدم ممارسات غير كافيةِ لمكافحة العدوى بغرف العمليات بمستشفيات بورسعيد.، لذا أوصت الدراسة بضرورة العمل على تحسين معرفةٍ و اتجاهات وممارسات فريق التمريض المتعلقة بمكافحه العدوى في غرف العمليات. وكذلك من خلال البر امج و الدور ات التدريبية والمؤتمرات و الندوات المستمرة بمكافحة العدوى لكي تساعدهم على تحسين معر فتهم وممارستهم و اتجاهاتهم بصفة مستمرة. 